\title{
COMPARISON OF TWO IN-LINE BLOOD WARMERS
}

\author{
M.S. Cherry, G.H. Hodgson AND H. NotTebrock
}

\begin{abstract}
We compared a new blood warmer, the Gorman-Rupp DW-1000A Blood Fluid Warmer, with the blood warmer currently being used at our hospital (the Hemokinetitherm). Using dated stored whole blood, we compared the heating capacities of the two blood warmers at varying flow rates. We found that the Gorman-Rupp (DW-1000A) was capable of faster infusion rates than the Hemokinetitherm and could consistently heat the blood to a higher temperature. Maximum flow rates of the Hemokinetitherm using a pressure bag at $79.8 \mathrm{kPa}(600 \mathrm{~mm} \mathrm{Hg})$ was $125 \mathrm{ml} / \mathrm{min}$ compared to a maximum infusion rate of $166 \mathrm{ml} / \mathrm{min}$ with the $\mathrm{DW}-1000 \mathrm{~A}$. The extent of blood warming at the maximum infusion rate was from $10.6^{\circ} \mathrm{C}$ to $28.5^{\circ} \mathrm{C}$ for Hemokinetitherm, compared with $10.6^{\circ} \mathrm{C}$ to $32.5^{\circ} \mathrm{C}$ for the DW-1000A. We conclude that the DW-1000A is superior to the blood warmer we have been currently using in both heating capabilities and maximum possible infusion rate.
\end{abstract}

KEY WORDS: EQUIPMENT, blood warmers.

HYPOTHERMIA INCREASES THE RISK of ventricular fibrillation, particularly below the temperature of $28^{\circ} \mathrm{C}$, and supraventricular arrythmias are common below body temperatures of $33^{\circ} \mathrm{C}$. Russell estimated that $32^{\circ} \mathrm{C}$ would be the minimum acceptable output temperature for a blood warmer to maintain body temperature within the "safe" range. Other criteria of efficiency include minimal resistance to infusion and flow capabilities of up to $150 \mathrm{ml} / \mathrm{min}$.

We tested a new blood warming unit, the Gorman-Rupp DW-1000A, to assess its ability to meet these criteria. In addition we tested the Hemokinetitherm, which we were currently using, against the same criteria.

Unlike Russell, we tested both blood warmers using dated stored whole blood rather than iced saline.

\section{METHODS}

Using dated stored human blood we tested both the Hemokinetitherm and the Gorman-Rupp DW-1000A blood/fluid warmers in vitro. We measured input and output temperatures of the blood at various infusion rates (Figure 1.). Using a pneumatic tourniquet to maintain a constant pressure on the blood bag and, therefore, a con-

M.S. Cherry, M.D., Resident; G.H. Hodgson, M.B., F.R.C.P.(C), Associate Professor; Department of Anaesthesia, University of Saskatchewan; Mr. Hank Nottebrock, Director of Electronics; Plains Health Centre, 4500 Wascana Parkway, Regina, Saskatchewan, S4S 5W9.

Canad. Anaesth. Soc. J., vol. 28, no. 2, March 1981

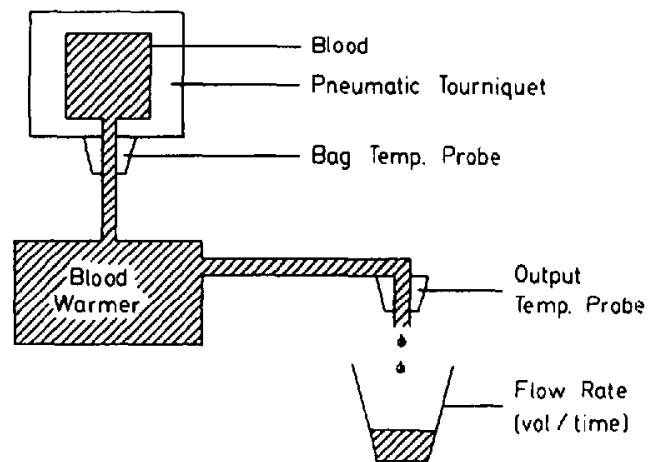

Figure I Diagramatic representation of method used for measurement.

stant blood infusion rate for any given pressure, we measured the infusion rate of blood issuing from the free end of the intravenous tubing of the blood warmer being tested. Infusion rates for the blood were measured/at bag pressure of 13.3, 53.2 and $79.8 \mathrm{kPa}(100,400$, and $600 \mathrm{~mm} \mathrm{Hg})$. The specifications for the individual blood warmers and their tubings are listed in Table $I$.

\section{Discussion}

The results given in Table II show that at each of the three bag pressures the DW-1000A is capable of faster infusion rates. By measuring the infusion rates at the same bag pressures for both blood warmers we eliminated the need to measure the resistance to flow introduced by the blood warmers. The results also show that the 
TABLE I

Blood Warmer Specifications

\begin{tabular}{|c|c|c|}
\hline & Hemokinetitherm & DW-1000A \\
\hline Weight & $9.1 \mathrm{~kg}$ & $3.2 \mathrm{~kg}$ \\
\hline Heat power & 600 watts & 360 wâtts \\
\hline Safety thermostat(s) & 1 & 2 \\
\hline $\begin{array}{l}\text { Heating time } \\
\quad\left(\text { to } 37^{\circ}\right)\end{array}$ & $10 \mathrm{~min}$. & $1 \mathrm{~min}$. \\
\hline $\begin{array}{l}\text { Safety thermostat } \\
\text { alarm } \\
\text { Infusion tubing }\end{array}$ & no & yes (audible) \\
\hline diameter (inside) & $3.0 \mathrm{~mm}$ & $2.5 \mathrm{~mm}$ \\
\hline $\begin{array}{l}\text { Mechanism of } \\
\text { heating }\end{array}$ & $\begin{array}{l}\text { Water bath } \\
\& \text { coiled tubing }\end{array}$ & $\begin{array}{l}\text { Dry heat cylinder } \\
\text { \& plastic warming cuff }\end{array}$ \\
\hline
\end{tabular}

TABLE II

\begin{tabular}{cccc}
\hline \hline $\begin{array}{c}\text { Blood Bag } \\
\text { Temp }{ }^{\circ} \mathrm{C}\end{array}$ & $\begin{array}{c}\text { Infusion } \\
\text { Rate } \\
\text { mls/min }\end{array}$ & $\begin{array}{c}\text { Output } \\
\text { Temp }{ }^{\circ} \mathrm{C}\end{array}$ & $\begin{array}{c}\text { Bag Press } \\
\text { mmHg }\end{array}$ \\
\hline $\begin{array}{l}\text { Hemokinetitherm } \\
7.3\end{array}$ & 52 & 34.5 & 100 \\
9.6 & 98 & 30.3 & 400 \\
10.4 & 125 & 28.5 & 600 \\
DW-1000A & & & \\
11.0 & 60 & 34.6 & 100 \\
10.6 & 120 & 32.2 & 400 \\
10.6 & 166 & 32.5 & 600 \\
\hline
\end{tabular}

DW-1000A had a greater heating capacity than the Hemokinetitherm. However, we did note that at the initial slower infusion rate there was a lower bag temperature for the Hemokinetitherm. This was due to technical difficulties at the beginning of the testing, but it can be seen by calculating the temperature difference between input and output for any given infusion rate that the DW$1000 \mathrm{~A}$ did heat the blood to a greater extent than did the Hemokinetitherm. The results pertaining to the heating capabilities and infusion rates obtained for the DW-1000A are of interest; they compared favourably with results obtained by Russell for the Fenwal blood warmer, which he considered to be the best of those warmers he tested; that is, the output temperature at flows of approximately $160 \mathrm{ml} / \mathrm{min}$ was just over the $30^{\circ} \mathrm{C}$, but it should be noted that those results were obtained using free flow and the solution being infused was iced saline.

We are presently using the Gorman-Rupp DW-1000A blood warmer regularly in the operating room and have found it quite satisfactory and simple to use. However, it should be noted that the thermostat circuits within the unit are not enclosed in a water-proof cover and, therefore, can short out if exposed to excessive moisture.

\section{REFERENCE}

1. W.J. Russell. A Review of Blood Warmers for Massive Transfusion, Anaesthesia and Intensive Care, 2: 109-130 (1974).

\section{RÉSUMÉ}

Nous avons comparé un nouvel appareil à réchauffer le sang, le DW-1000A de Gorman-Rupp. à l'appareil Hemokinetitherm qui est d'usage courant dans notre milieu hospitalier. La capacité de réchauffement du sang de banque à divers débits des deux appareils a été étudiée.

Nos résultats démontrent que l'appareil de Gorman-Rupp permet de plus grands débits sanguins que l'Hemokinetitherm et réchauffe davantage le sang. Avec une pression de $79.8 \mathrm{kPa}(600 \mathrm{~mm} \mathrm{Hg})$ dans un sac à pression, on pouvait obtenir des débits maxima de $125 \mathrm{ml} / \mathrm{min}$ avec l'Hemokinetitherm et de $166 \mathrm{ml} / \mathrm{min}$ avec le $\mathrm{DW}-1000 \mathrm{~A}$. A ces débits maxima, le sang passait de 10.6 à $28.5^{\circ} \mathrm{C}$ avec l' Hemokinetitherm et de 10.6 à $32.5^{\circ} \mathrm{C}$ avec le DW-1000A. Nous concluons que le DW-1000A est supérieur à l'appareil que nous avons utilisé dans notre milieu du double point de vue capacité de réchauffement et débit maximum. 